Systematic Review

\title{
Mediation and Online Learning: Systematic Literature Mapping (2015-2020)
}

\author{
Gioconda Riofrío-Calderón ${ }^{1, *(1)}$ and María-Soledad Ramírez-Montoya ${ }^{2}$ \\ 1 Department of Education Sciences, Universidad Técnica Particular de Loja, Loja 110107, Ecuador \\ 2 Institute for the Future of Education, Tecnologico de Monterrey, Monterrey 64849, Mexico; solramirez@tec.mx \\ * Correspondence: gcriofrio@utpl.edu.ec; Tel.: +593-998-413-758
}

Citation: Riofrío-Calderón, G.; Ramírez-Montoya, M.-S. Mediation and Online Learning: Systematic Literature Mapping (2015-2020). Sustainability 2022, 14, 2951.

https://doi.org/10.3390/su14052951

Academic Editors: Juan Quemada Vives, Aldo Gordillo and Enrique Barra Arias

Received: 31 January 2022

Accepted: 21 February 2022

Published: 3 March 2022

Publisher's Note: MDPI stays neutral with regard to jurisdictional claims in published maps and institutional affiliations.

Copyright: (C) 2022 by the authors. Licensee MDPI, Basel, Switzerland. This article is an open access article distributed under the terms and conditions of the Creative Commons Attribution (CC BY) license (https:// creativecommons.org/licenses/by/ $4.0 /)$.

\begin{abstract}
Mediation is a crucial element in the learning process, especially in a virtual environment, whether it corresponds to formal, non-formal, or informal education. This paper aims to expose the research on mediation and learning in virtual environments published between 2015 and 2020. A total of 299 articles were identified that address the topic of mediation and learning in virtual environments from different fields and approaches. The results that respond to the research questions are presented. The study was carried out with the Web of Science (WOS) and Scopus databases, and inclusion and exclusion criteria were applied to obtain the articles under study. The Systematic Literature Mapping (SLM) method was used to answer questions raised for analysis. Information was extracted from the articles regarding the method used, the most cited articles, geographical distribution of the authors by country, the journals and impact factor, type of mediation, and finally, the trends and spaces where mediation takes place. The results show studies tending toward technological mediation and factors such as interaction, collaboration, communication, and discussion, among others. The practical implications are oriented to show the mediating factor from the pedagogical and technological perspectives and its contribution to achieve meaningful learning.
\end{abstract}

Keywords: mediation; education; online learning; systematic literature mapping; educational innovation; higher education

\section{Introduction}

The educational process has changed thanks to innovative pedagogical factors that open new educational possibilities and development of Information and Communication Technologies (ICTs). The latter are ubiquitous and offer ease of access to a large part of the global population. These factors constitute part of the goals set out in the United Nations 2030 agenda, addressing education and lifelong learning opportunities for all [1]. Lifelong learning is necessary for business, educational, health, social, political, and other contexts. Every day, it is necessary to renew and optimize products and services. Human beings must respond with qualified training. In this scenario, mediation acquires special significance. It assumes a leading role in the teaching-learning process. We must take care that the strategies, resources, and content (in short, the instructional design) are effective and achieve the learning results, regardless of whether the training is face-to-face, blended, distance, or online.

Today, Information and Communication Technologies (ICT) and internet access are gaining ground in this mediated educational process. In Latin America and the Caribbean, the number of households connected to the Internet between 2010 and 2016, according to Economic Commission for Latin America and the Caribbean (CEPAL) [2]. Therefore, it is necessary to enhance the benefits of online learning. It is essential to consider that the use of technologies in education by teachers and students generates a critical and creative space, provoking social and cultural vision [3]. Technologies such as the Internet, Web 2.0 and improved mobile devices have supported the emergence of online education [4]. This educational modality is growing, revealed by increasing enrollment [5]. 
Students prefer technology, especially social networks, so teachers are called to change their teaching-learning methods to adopt and adapt to computers and technologies [6]. In higher education, incorporating ICT, more than the automation of management processes, provides the vision for the evolution of training and learning processes [7]. As can be seen at a time of solid technological presence, the educational field must promote didactic processes in which technologies become the best allies to deal with a constantly changing world.

As it has been pointed out, online education is supported by Communication Technologies (ICT); however, a virtual learning environment is not enough, in this case, if a mediated education is intended from technologies, the elements that are part of the process must lead to significant learning [8], so it is worth highlighting the relationship between Technologies, Mediation, Learning. Regarding this relationship, [9] point out that in human communication, in addition to the word, history continues to be written through technological mediations, taking into account that scenarios mediated by technology allow education, which is not limited even in time and space. The relationship between these three aspects is key, when it is affirmed that the mediation promoted by technologies is fundamental for the learning process [10], as also confirmed by [11] when they refer to distance education, they consider that virtual courses should use different mediations to achieve the process of self-formation of the person. This shows the link between the elements of mediation, learning and technology, which together and well directed contribute to a quality online educational process.

The vertiginous technological change has occurred by chance; it has been accompanied by a fundamental factor, innovation, which today is a topic in all areas, especially in education. We can say that educational innovation is anything new that promotes or improves students' learning, even if it is an adaptation of organizational, administrative, or pedagogical areas [12]. Therefore, in pedagogical innovation, one of the most valuable elements is communication [13]. It is worth reflecting that although technology has brought improvements to our lives, innovation is the act of doing something different and better; thus, in education, innovation achieves increasingly excellent learning results using the same or less time and resources [14]. On the one hand, technology is essential but, accompanied by innovation in the educational field, the two are a perfect duo for an effective process. This should be the educational context: integrating technology with innovation as a contribution to the educational process.

There is a mediating element in the educational process with technologies and innovation, referred to as mediation or mediated learning. Mediation is conceived as a humanizing, positive factor, with a constructivist, empowering scope in the educational relationship [15]. Mediation as a pedagogical practice is a process of supporting another person, team, or community to solve problems and generate products through continuous feedback [16]. It is also the relationship between the learner and the social interaction [17]. Mediation enables the enhancement and release of the person's potential through their gradual development to reach the highest level of autonomy in learning [18]. According to the Mediated Learning Theory, it occurs in two ways: direct exposure to stimuli and a mediated learning experience [19]. As to what is achieved by mediation, the learning that occurs should solve problems and even generate new learning [20]. As can be seen, mediation from its conception acts in the educational process as a mechanism to support and strengthen students' development.

To understand the mediating task, one must focus on learning in virtual environments. It should be noted that human learning is more than a behavior change; it also implies a change in the meaning of human experience, which is not only thought but also affectivity [21]. Along these lines, some forms or strategies are used to achieve meaningful learning, all according to how the student learns and what the learning means; they are the strategies and constructivist resources used to learn; thus, we speak of online learning and collaborative, blended, mobile, project-based, and social learning, to name a few. Some of the studies we reviewed prioritize online learning, which is considered a tool to make the teaching-learning process student-centered, innovative, and flexible [22]. Reference [23] 
agrees about innovativeness when he points out that online spaces allow many innovative approaches to support learning. The innovative dynamics present in online education are no longer conceived as a trend but relatively mainstream, especially at the higher levels of education [24]. Online learning has gained popularity worldwide because traditional education's temporal and spatial problems are reduced [25]. Fundamentally, due to the COVID-19 pandemic, online learning became the worldwide response to the emergency training need that represented a global before-and-after moment.

Another form of learning that is a trend in virtual environments is collaborative learning. This learning is usually defined as two or more people working together to pursue a shared learning goal [26]. It is further said that this type of learning requires learners to articulate their views while listening to the views of others for knowledge creation [27]. Collaborative learning fundamentally also addresses interaction, and if we talk about resources, the Wiki is a tool widely used on virtual platforms; therefore, it is a booming type of learning. It is also interesting to study blended learning, also known as mixed or hybrid, referring to joining traditional classroom teaching methods with online learning, i.e., we speak of a combination of face-to-face and technology-mediated learning [28]. The authors [29] agree that blended learning is a mixture of online and face-to-face learning. It seems to be most used in higher or adult education, even though blended learning courses usually require more preparation time than traditional courses [30]. As can be observed, this form of learning is currently in evidence. Technology is its main ally at a time when online training is gaining ground.

Mobile learning, known as m-learning, involves mobile media or resources. Mobile learning refers to learning with mobile devices such as phones and tablets [31]. Regarding this form of learning, Reference [32] state that it is a relatively new field of study and that at the moment, few studies collectively analyze the topic. It should be noted that m-learning has become an important component of educational technology for higher education, allowing students to learn, collaborate and share ideas thanks to technological development [33]. Project-based learning requires students to work together to build knowledge and find solutions to authentic problems [34]. This type of learning constitutes a learner-centered teaching method that seeks to develop the learner through means relevant to his or her life [35]. Furthermore, project-based learning requires interdisciplinarity, working together as a community, and contributing to problem-solving in a real-world context [36]. Like other forms of learning, both m-learning and project-based learning are strategies that enable contextual student learning according to the means available to them.

To find out if there are other studies related to mediation in virtual environments, we reviewed the database, and 21 articles were found to be literature reviews, of which 13 were located in the WOS database and eight in SCOPUS. These studies addressed areas such as mediated communication, mediated learning, e-learning, hybrid learning, social networks, feedback, and collaborative writing, among others. Although they are related to the topic of interest of this work, we observed that they focused on specific topics such as communication, student participation, the role of facilitator, data mining, academic performance, or dialogue in the classroom. In other words, they contemplated elements such as mediation and learning in virtual environments, but their interests were in specific elements. On the other hand, some studies covered a smaller range of years than the present study, analyzed a reduced number of articles, or based their study on a single country. These studies are necessary inputs for online training and contribute to strengthening the academic environment with their results.

However, similar studies were found on systematic mappings that allowed defining some questions that serve as a reference for the present study; for example, it is affirmed that methodological designs play an important role [37], therefore, a question that investigates this aspect was included. Another of the publications analyzed within the literature reviews was the country to which the authors belong, which shows where the studies mostly come from. This is how we found the work called Training in Digital Competencies for Health Professionals: Systematic Mapping (2015-2019) [38]. As mentioned in the 
previous paragraph, the literature reviews that emerge from the search chain do not address the same questions and aspects of interest the topics as in this study; however, it is important to highlight the literature review's identification and prioritization of critical issues for the promotion of e-learning in Pakistan, where the analysis focuses on the critical e-learning themes [39] and Trends in Educational Research about e-Learning: A Systematic Literature Review (2009-2018), which addresses e-learning as a technology-mediated learning approach [40].

On the other hand, in other literature reviews identified in the search for the present research, those that address technological mediation were located, taking into account the fact that the use of technology to deliver content, interact with students, and study from any time and place has increased [41]. In addition to technological mediation, it is useful to verify what has been published regarding pedagogical mediation and even greater if both types of mediation go hand in hand, so when referring to technological mediation in education, it is stated that it is an area that has been gaining strength at the same time as the development of technological innovations, and what they imply for teaching, thus, in online education, is that both the use of ICT and the training of people for the pedagogical use of ICT have become relevant and from this perspective pedagogical mediation is relevant [42].

This article analyzes the research published between 2015 and 2020 on mediation and virtual learning environments to identify the approach to mediation, its typology, and how the online formative process occurs. We are interested in knowing what has been researched and which elements are shown to be key factors. Based on this objective, the research was carried out through systematic mapping. We explored vital elements that allowed us to identify what has been researched on the subject globally. With the answers to the six research questions, results were obtained and these exposed and reflected over the focus and direction of the research on mediation and online learning. Systematic mapping is a methodology that allows visualizing in a quantified way the place of a certain topic in a research field, and even with selected publications can the reader incorporate other types of more in-depth reviews of the literature. The present research differs from previously published studies in that it is a systematic mapping and contributes to the literature on mediation and online learning. It contributes to the academic community, teachers, managers, decision-makers, and the general public with elements that improve mediation in virtual environments.

\section{Materials and Methods}

\subsection{Method}

We performed a systematic mapping of literature and presented the analyzed results according to guiding questions, data, and contributions to mediation in online training environments. The mapping strategy allows the researcher to identify what has been published in a given period and the approaches addressed. For the development of the work, the contributions of [43-47] were taken as a reference. Furthermore, the authors provide in their writings and methodology the characteristics and advantages of this type of studies. Figure 1 presents the methodological process for the mapping performed.

\subsection{Definition of Scope and Objective (Research Questions)}

For our systematic mapping, the process began with the formulation of research questions, which is the central axis of mapping because it supports an overview of a given area [47]. For the present case, six research questions were defined (Table 1), which made it possible to quantify the studies carried out in each period and ascertain the context and the areas addressed by the selected studies.

\subsection{Inclusion and Exclusion Criteria}

The inclusion and exclusion criteria are constituted by the information that is or is not relevant according to the type of study. According to the systematic mapping and the questions posed, some inclusion criteria were defined to identify studies published 
between January 2015 and November 2020 in the two databases. The databases chosen were Web of Science and Scopus because, in the academic world, they are two of the most relevant databases of scientific journals [48]. Regarding the type of document, only journal articles were selected that contemplated mediation and learning in virtual environments. The exclusion criteria were the years before 2015 and books, book chapters, conference proceedings, reviews, etc. As reference [44] mentioned, the inclusion and exclusion criteria should come from the research questions; therefore, there is a direct relationship between these elements. Table 2 presents the criteria for the study.

\begin{tabular}{|l|l|}
\hline Step 1 & -Definition of Scope and Objective (Research Questions) \\
\hline Step 2 & -Inclusion and Exclusion Criteria \\
\hline Step & - Extraction of the Articles through Database Searches \\
\hline
\end{tabular}

Figure 1. Methodological process for the design of the mapping.

Table 1. Research questions.

\begin{tabular}{|c|c|}
\hline Question & Type of Response Sought \\
\hline $\begin{array}{l}\text { RQ1: How many studies are in the WOS and Scopus databases from } \\
\qquad 2015 \text { to } 2020 \text { ? }\end{array}$ & $\begin{array}{c}\text { Number of articles in WOS } \\
\text { Number of articles in Scopus } \\
\text { Number of duplicated articles } \\
\text { Number of articles with quantitative, qualitative, and mixed methods } \\
\text { and research design }\end{array}$ \\
\hline RQ2: Who are the authors of the most cited articles? & Most cited articles \\
\hline RQ3: What is the geographical distribution of the authors? & Countries where the authors are from \\
\hline $\begin{array}{l}\text { RQ4: What are the journals that have the most publications on this } \\
\text { subject? }\end{array}$ & Journals Q1, Q2, Q3, Q4 \\
\hline RQ5: What type of mediation is presented in the articles? & $\begin{array}{c}\text { Technological } \\
\text { Pedagogical } \\
\text { Social } \\
\text { Parental }\end{array}$ \\
\hline RQ6: What are the trends that are addressed in the articles? & $\begin{array}{c}\text { Type of learning empowered } \\
\text { The educational level where the research is generated, virtual spaces, or } \\
\text { technology and tool used. }\end{array}$ \\
\hline
\end{tabular}

Table 2. Inclusion and exclusion criteria.

\begin{tabular}{cc}
\hline Inclusion Criteria & Exclusion Criteria \\
\hline Databases: WOS and Scopus & Other databases \\
\hline Studies published between 2015 and 2020 & Studies from years before 2015 \\
\hline Documents: only articles & $\begin{array}{c}\text { Reviews, conferences, book chapters, books, articles in reports, series, } \\
\text { and studies of these in press. }\end{array}$ \\
\hline $\begin{array}{c}\text { Articles: only from journals } \\
\text { Articles from the educational field that address mediation in online } \\
\text { environments }\end{array}$ & $\begin{array}{c}\text { Studies that address mediation as a conciliation or peace process or } \\
\text { cases of educational conflict resolution. }\end{array}$ \\
\hline
\end{tabular}




\subsection{Identificacion of Databases and Search Terms}

According to the inclusion criteria, the WOS and Scopus databases were selected to search for publications, using a search string with similar criteria in both databases. To avoid the possibility of certain publications being left out due to the terminology used, we used similar terms and Boolean operators to perform the search [49]. The search criteria are presented in Table 3.

Table 3. Search strings in Scopus and WoS.

TITLE-ABS-KEY ((“pedagogical mediation” OR “*mediated learning*” OR "mediated Communication")) AND TITLE-ABS-KEY (("e-learning" OR “online education" OR “virtual education" OR "Virtual learning environment" OR "Computer Aided Instruction" OR "Massive Open Online Course" OR "MOOC"))) AND (LIMIT-TO (PUBYEAR, 2020) OR LIMIT-TO (PUBYEAR, 2019) OR LIMIT-TO (PUBYEAR, 2018) OR LIMIT-TO (PUBYEAR, 2017) OR LIMIT-TO (PUBYEAR, 2016) OR LIMIT-TO (PUBYEAR, 2015)) AND (LIMIT-TO

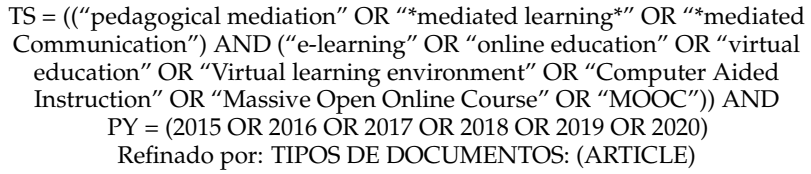

$\mathrm{TS}=\left(\left(\right.\right.$ "pedagogical mediation" OR "*mediated learning" ${ }^{*} \mathrm{OR}$ "*mediated Communication") AND ("e-learning" OR "online education" OR "virtual education" OR "Virtual learning environment" OR "Computer Aided Instruction" OR "Massive Open Online Course" OR "MOOC")) AND PY = (2015 OR 2016 OR 2017 OR 2018 OR 2019 OR 2020) Refinado por: TIPOS DE DOCUMENTOS: (ARTICLE) (DOCTYPE, "ar"))

\subsection{Database Search and Article Retrieval}

The selection of criteria to filter the chosen articles was performed through a series of steps categorized by level, starting from the general context of mediation, mediated communication, and learning, developed in an online environment, corresponding to the period 2015-2020, and finally, journal articles. First, the inclusion and exclusion criteria were established, according to the process of [49]. Starting from the search criteria overview, we found 118 articles in Scopus and 290 in World of Science, 408 articles total. The result was 330 publications, of which 31 publications were excluded for other reasons, among which it is noted that 21 of them were literature reviews, which for this type of publications are not considered within the base, in another 10 cases the publications, although they include the search terms, the interest was focused on areas such as health, agriculture, labor, evaluation processes, nutrition, architecture and energy; therefore, there is no greater relationship with the chosen topic, leaving the final base with 299 publications that constitute the database for this work. These steps are shown in Figure 2 according to the PRISMA statement [50].

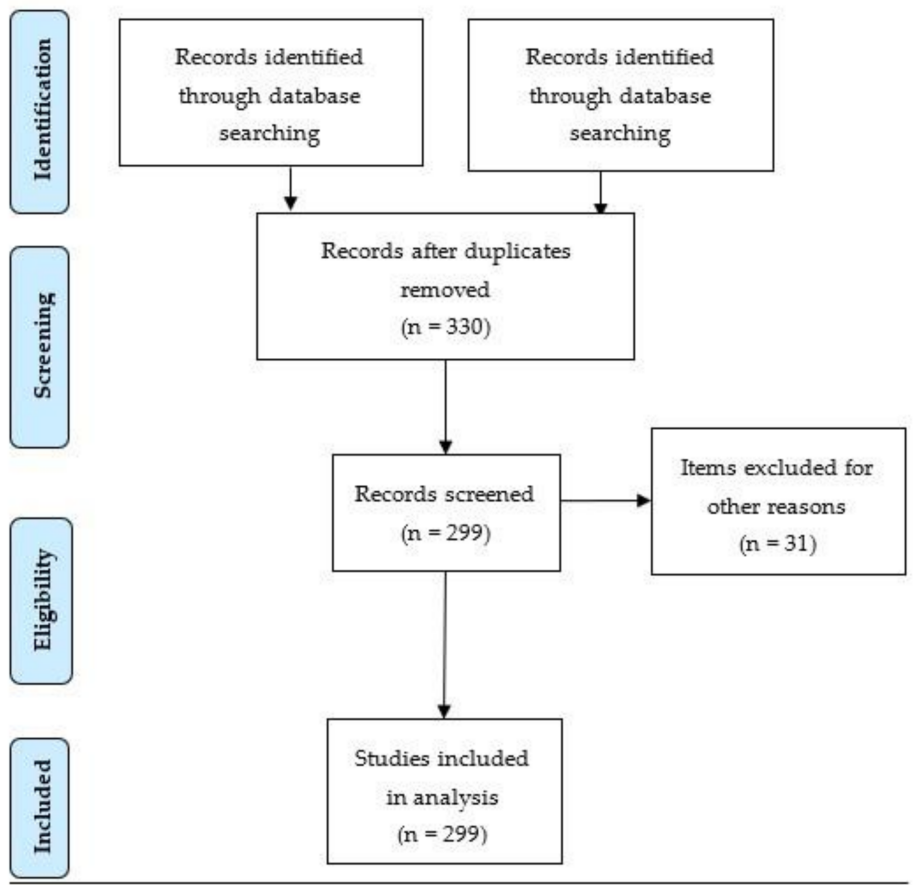

Figure 2. PRISMA 2009 flow diagram for the systematic literature mapping. 


\subsection{Creation of the Classification Scheme}

After the quantitative analysis, a qualitative process analyzing the articles' summaries let us identify the types of mediation addressed in the publications and categorize them as technological, cognitive or pedagogical, social, and parental mediations, the latter also associated with the teaching-learning process represented in the Table 4.

Table 4. Categories in the review of studies on types of mediation.

\begin{tabular}{ccc}
\hline Types of Mediation & Description & Theoretical Sustenance \\
\hline Technological & $\begin{array}{c}\text { Studies that analyze mediation but more } \\
\text { associated with the media and the } \\
\text { communicative process mediated by technology. }\end{array}$ & $\begin{array}{c}\text { Technological mediation is not reduced to the technological } \\
\text { aspect. It also involves cognitive and social. }\end{array}$ \\
\hline Technological & $\begin{array}{c}\text { Dimensions oriented to the integral formation of the } \\
\text { human being. This process favors both the individual and } \\
\text { collaborative aspects, based on different tools [17]. }\end{array}$ \\
\hline Pedagogical or cognitive & $\begin{array}{c}\text { This category groups together those studies that } \\
\text { aim to analyze mediation from a pedagogical or } \\
\text { cognitive perspective and refer mainly to } \\
\text { strategies in the teaching process. }\end{array}$ & $\begin{array}{c}\text { Pedagogical mediation refers to the treatment of contents } \\
\text { and the forms of expression of the different subjects to } \\
\text { make the educational act possible. As a result, there is } \\
\text { student participation, creativity, relationship, and } \\
\text { interactivity [51]. }\end{array}$ \\
\hline Social & $\begin{array}{c}\text { Corresponds to those studies that approach } \\
\text { mediation from a context of collaborative } \\
\text { training, in pairs, through social networks, that } \\
\text { is to say, within a group, participative criterion. }\end{array}$ & $\begin{array}{c}\text { Learning with mobile, smart devices, and social networks } \\
\text { is a trend that has modified traditional learning. Moreover, } \\
\text { a direct relationship is established between mediation, } \\
\text { sense of relevance and social presence [52]. }\end{array}$ \\
\hline Parental & $\begin{array}{c}\text { In this group are publications referring to } \\
\text { mediation executed by parents through the } \\
\text { control of their children, especially at school age. }\end{array}$ & $\begin{array}{c}\text { Parental mediation tends to be more negative than positive } \\
\text { as it focuses on advice, rules and prohibitions in using the } \\
\text { Internet [53]. }\end{array}$ \\
\hline
\end{tabular}

In the educational context, especially in online environments, technology and innovation are essential allies for mediation. Indeed, the imprint of ICT has made it possible to study the integration of tools and the influence on cognitive and social dimensions [17]. Authors such as in [51] focused their attention on pedagogical processes in interaction with cognitive variables. Other studies integrate pedagogical and social processes in collaborative training with participation in social networks [52]. Finally, in the same educational context, parental mediation was primarily related to strategies of control and support of internet use [53].

\section{Results}

The information was processed in an Excel database, where answers were given to each research question. The database contained 299 publications. The publications had an identifying number [in square brackets], which were referenced in the answers to the mapping questions. The access site to the database of the articles under study can be found at the following address: http:/ / doi.org/10.5281/zenodo.4744632 (accessed on 10 January 2022).

\subsection{SRQ1: How Many Studies Are in WOS and Scopus Databases from 2015 to 2020, and What Is Their Design?}

Of the 299 articles obtained in the two databases, the results turned up 108 articles in Scopus, of which 51 worked with quantitative methods, 39 with qualitative methods, and 18 with mixed methods. The WOS database contained 191 articles, 75 with quantitative methodology, 66 with qualitative, and 50 with mixed methods. As can be seen, the quantitative method dominates in the experimental design. Regarding the approach of qualitative, quantitative or mixed methods in research, the choices were based on the interest of the researchers, leading them to choose one of these approaches [54]. Thus, the paths used by the researcher to meet desired objectives were the design methods that considered relationships, strategies, and techniques [55] shown in the Figure 3. 


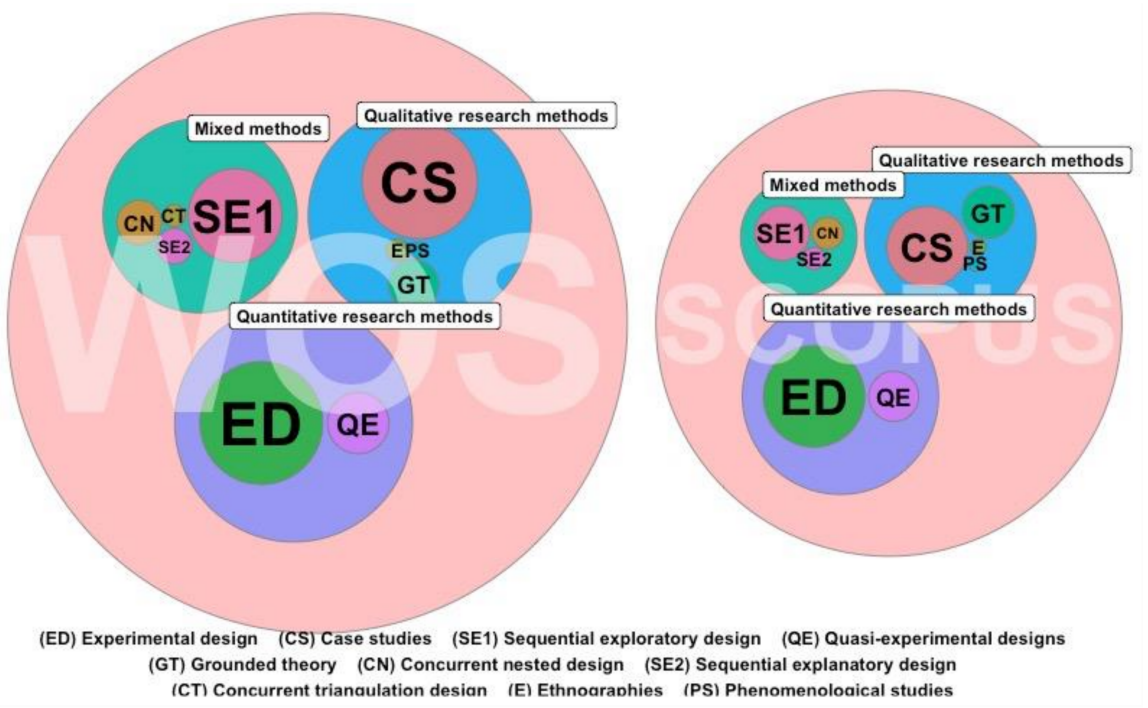

Figure 3. Number of articles identified in Scopus and WOS from 2015 to 2020 by type of methodology.

Some examples of research that respond to these findings, according to this type of methodology are based on SCOPUS and use quantitative methodology [56-59], use qualitative methodology [60-63], and use mixed methods [64-67]. In the WOS database, we cited some cases of articles with quantitative methodology [68-71], qualitative [72-75] and mixed methods [76-79].

\subsection{RQ2: What Are the Most Cited Articles?}

According to the results, the article "Together we are better: Professional learning networks for teachers by the authors" [75] had the highest number of citations (93), published in the journal Computers and Education. This article focuses on investigating professional learning networks. It highlights the importance of the diverse interests and needs of educators in the digital age. Figure 4 lists the articles with 30 citations and above, a total of 24 publications, which are further identified by the number [in square brackets], as recorded in the database.

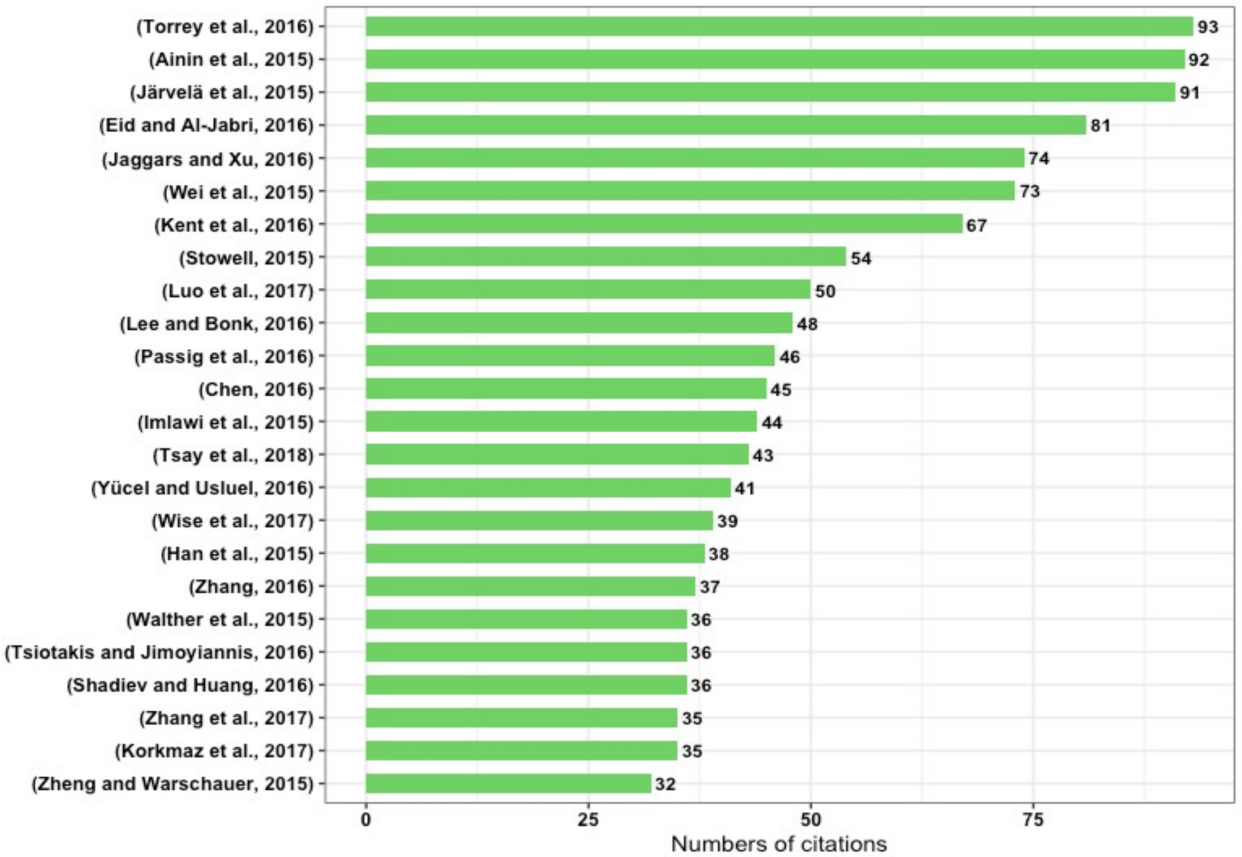

Figure 4. Most cited articles (the first 24 places), [75], [71], [80-91], [65], [92-100]. 
As can be seen, the academic community is interested in areas such as networked learning, collaborative learning, open courses, interaction, and MOOCs. In some cases, these investigations are about teachers. Others fall under the gaze and interest of students. Therefore, it is essential to continue to deepen these analyses and also verify areas that, as a result of the COVID-19 pandemic, have had greater interest from the international community.

\subsection{RQ3: What Is the Geographical Distribution of the Authors?}

Figure 5 shows that the United States has the highest number of publications with 62, followed by Taiwan with 39, China 22, Spain 18, Australia 16, and the United Kingdom with 14 publications. Therefore, together with the United States, the Asian continent registered a very high interest in the topic. The geographical distribution was determined based on the publication's first author, regardless of the number of authors.

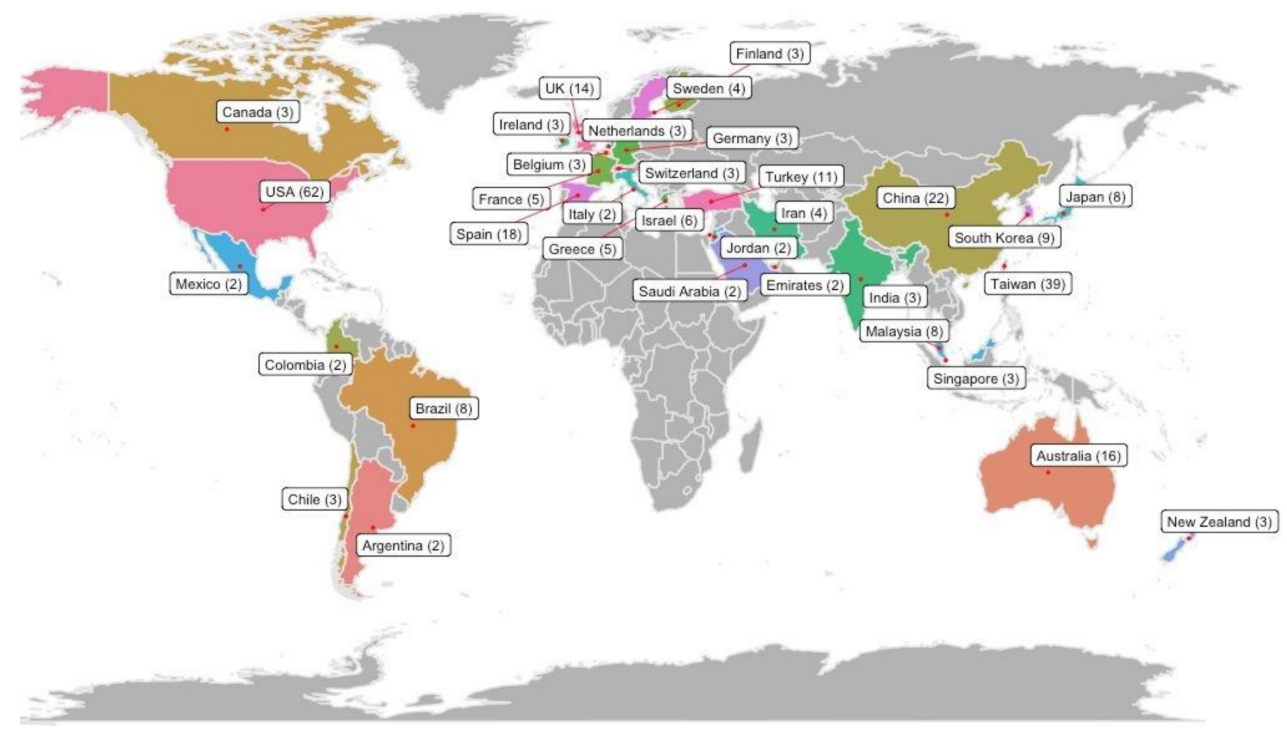

Figure 5. Geographical distribution of the authors.

The number of publications by country shows that although the research has been conducted in various countries, some regions such as Latin America and parts of Europe, lack publications on this topic. These have opportunity since the subject of mediation in virtual environments is sure to receive contributions from training experiences in academic, institutional, and business or other contexts.

It is important to consider that although the United States is the country with the most publications, within the findings it can be observed that the two publications with the highest impact in terms of citations are "Facebook usage, socialization and academic performance" in second place of most cited, from Malaysia [71], and "Enhancing socially shared regulation in collaborative learning groups: designing for CSCL regulation tools", from Finland [80]. Another example is the publication "Social networking, knowledge sharing, and student learning: The case of university students" from Saudi Arabia [81]; therefore, as can be seen, the presence and contribution of other countries to the topic addressed is important.

\subsection{RQ4: Which Are the Journals with the Most Publications on This Topic?}

Figure 6 shows the 20 journals with the highest number of published articles extracted from the Scopus and WOS databases. Eighty-eight publications belonged to the journal Computers and Education; the next-highest journal had 18 publications. In third place was the journal with 15 publications. All three were quartile one journals. The journals only with one or two publications were not considered. Figure 6 shows the number of 
publications per journal and its quartile (Q1, Q2, Q3 and Q4). The first 20 journals fell in the first three quartiles.

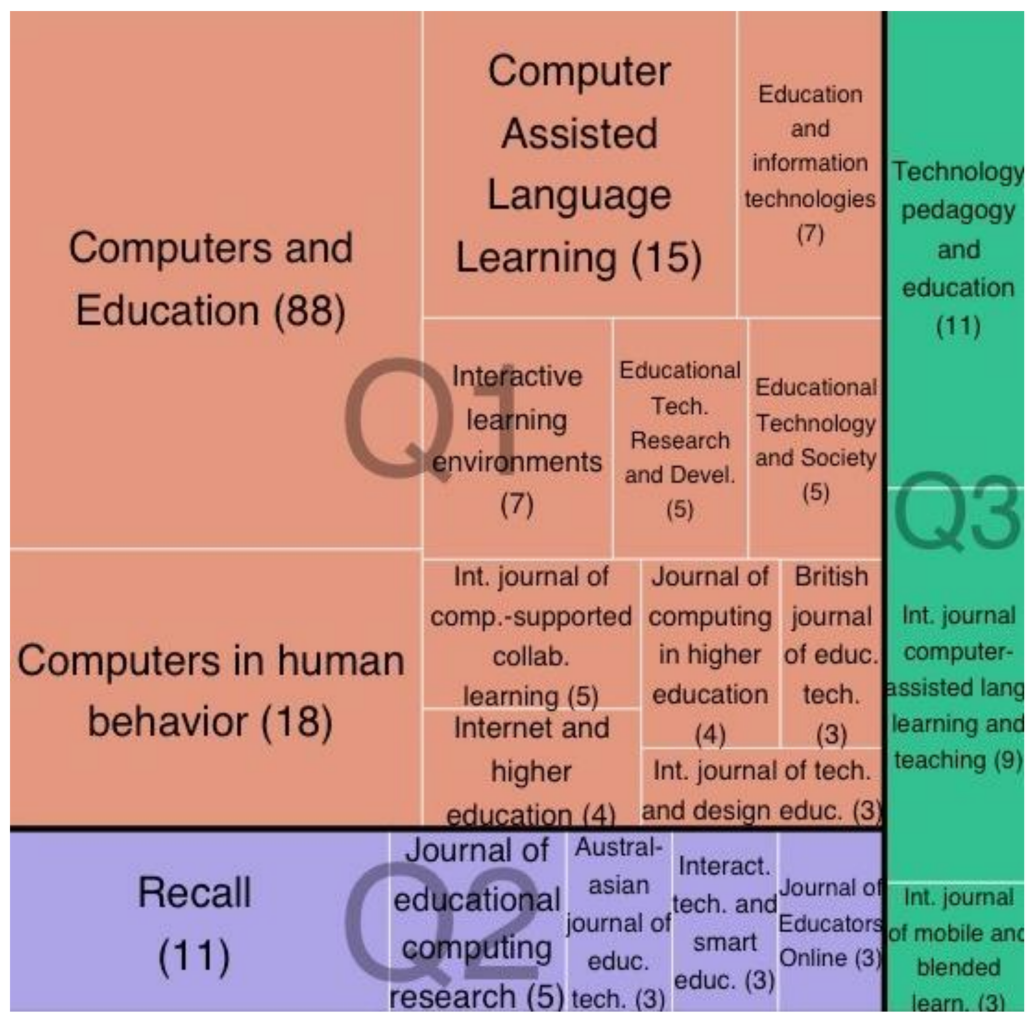

Figure 6. Journals with more than two articles published.

The diversity of journals publishing on the topic of interest in this study leaves an open door for researchers from different countries to contribute their writings in this area. In addition, there is a significant number of journals (more than 90) in the database whose interest is research in online learning and higher education distance learning and more. This is good news for those interested in the topic addressed.

\subsection{RQ5: What Type of Mediation Is Presented in the Articles?}

The results show that of the 299 publications, 196 corresponded to technological mediation, 72 pedagogical, 28 social, and three parental. Figure 7 shows the type of mediation and the keyword identified, i.e., the term that stands out most in the publication, making it possible to show which aspects are emphasized in the research or the subject of more analysis by the authors. In this context, it is noteworthy that although the articles emphasize the technological aspect, every educational process has an implicit pedagogical element designed to generate learning, which is the ultimate goal.

In technological mediation (Figure 7), terms such as learning, interaction, collaboration, communication, and motivation are highlighted, showing the importance of these areas to the authors. Similarly, in pedagogical mediation, learning, collaboration, and interaction are strongly emphasized, fundamental elements if one considers that the articles deal with mediation and online learning. Finally, in social mediation, interaction, motivation, and collaboration are highlighted, critical factors when speaking of learning in a social environment.

Some technological mediation publications identified these findings in the database with the type of technological mediation such as Surprise-enhanced and technologymediated learning: a two-country study [56], The personal experience of online learning: An interpretative phenomenological analysis [101], Technology-mediated synchronous virtual education: An empirical study [102], Technology-mediated learning theory [103], 
Writing as pedagogical mediation includes the necessary knowledge for online education: Teaching and learning to produce knowledge [104], Pedagogical usability: A theoretical essay for e-learning [105], LIES: Learning Immersive Experiences Significative [106], The Interplay of Game Design and Pedagogical Mediation in Game-Mediated Japanese Learning [107].

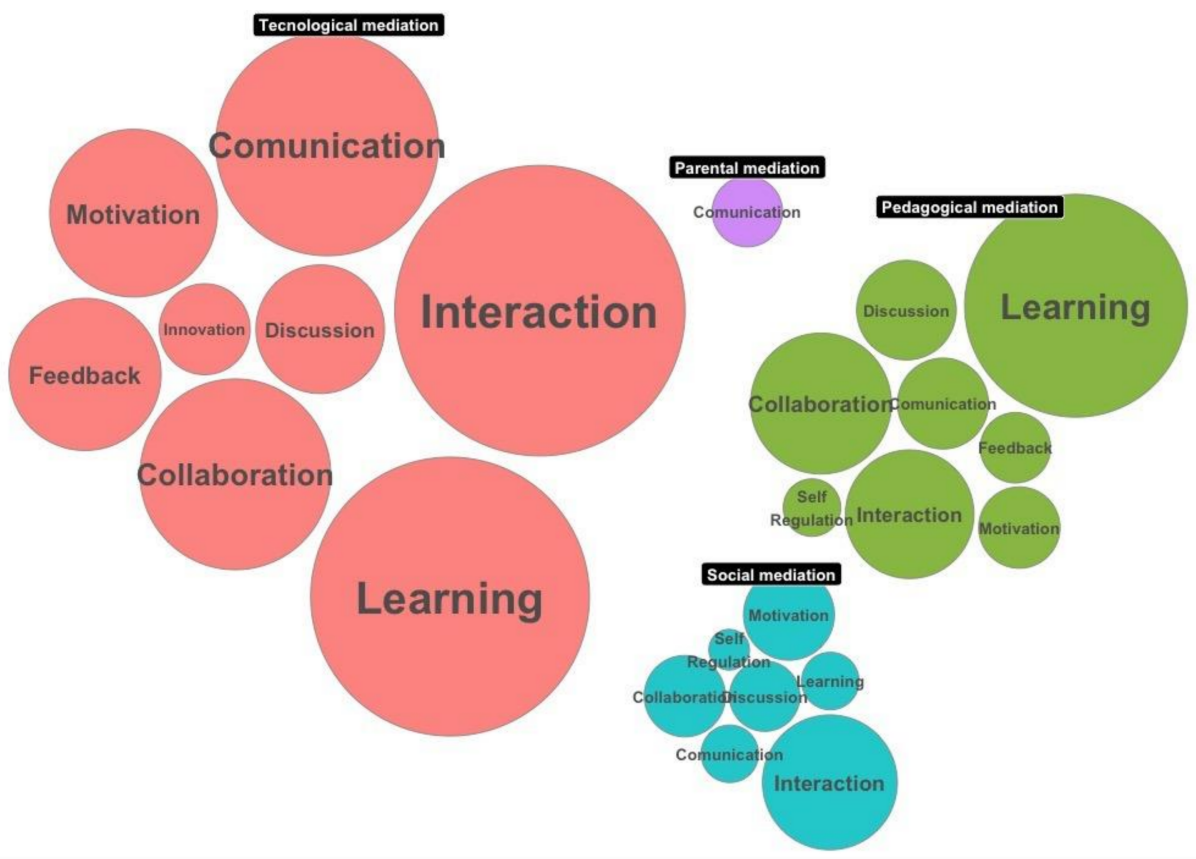

Figure 7. Mediation type and article keyword.

Social mediation has Social presence reconsidered: moving beyond, going back, or killing social presence [108], Social relations of cyber-mediated learning platforms: Symmetry, relation, and evolution [109], Exploring the impacts of interactions, social presence and emotional engagement on active collaborative learning in a social web-based environment [110], Role taking and knowledge building in a blended university course [111]. Finally, parental mediation includes Active and restrictive parental mediation over time: Effects on youths' self-regulatory competencies and impulsivity [112], The relative importance of paternal and maternal parenting as predictors of adolescents' home Internet use and usage [113], The perception of parents about the digital empowerment of family in hyperconnected households [114].

In addition to the type of mediation, the keyword is essential. Keywords are terms highlighted in the publications, which can draw the attention of researchers searching for a topic area. Learning, interaction, communication, collaboration, motivation, discussion, and others were the elements on which the articles focused and constituted areas of opportunity for research in mediation in virtual environments. Due to the pandemic beginning in 2020, face-to-face education migrated to obligatory virtual or emergency remote education. Therefore, it will be necessary to deepen investigations into the strategies that favor quality online training, which will undoubtedly interest all areas.

\subsection{RQ6: What Are the Trends Addressed in the Articles?}

Question 6 concerned the interest in knowing the type of learning promoted in the research. We identified that online learning, collaborative learning, mediated, blended, mobile, project-based, and social learning were addressed. The technological tools used with mediation and virtual learning environments were also approached. The publications cited tools and experience in virtual learning environments, online courses, mobile technology, social networks, etc. Fewer studies referred to the use of tools such as chat, videoconferencing, and forums. Although they are used in online courses or virtual environments, 
they were categorized independently to reflect the specific experience with these tools in this study.

On the other hand, it was necessary to link the type of learning and the tool used, and the educational level to which the research referred. As a result, we found 121 articles basing their work on higher education or university level; 63 articles did not specify the educational level in the research, while 56 publications concerned continuing education, and 28 covered primary or school education. The rest of the publications reported secondary and postgraduate education research.

Articles with findings on different types of learning are in the database, for example, online learning articles are located under the name of the personal experience of online learning: An interpretative phenomenological analysis [101], How do online course design features influence student performance? [82], Online research and learning in science: A one-to-one laptop comparison in two states using performance-based assessments [115], LOLsquared: When laughing-out-loud and learning-on-line intermingle in a computermediated classroom discussion [63].

From collaborative learning: Impact of pedagogic agent-mediated metacognitive support toward increasing task and group awareness in CSCL [116], The effects of synchronous $\mathrm{CMC}$ on English proficiency and social presence, affinity for partners: Text versus video chat between Japanese and Philippine EFL learners [117], Community technology mapping: inscribing places when "everything is on the move" [118], Blending Facebook discussions into seminars for practicing argumentation [119].

For his part of the blended learning: Student enrollment, motivation and learning performance in a blended learning environment: The mediating effects of social, teaching, and cognitive presence [120], The state of 21st century learning in the K-12 world of the United States: Online and blended learning opportunities for American elementary and secondary students [121], Parental monitoring predicts students' prosocial and impulsive tendencies relevant to consequence-based reasoning in a blended learning environment [122], Face-toface, blended, flipped, or online learning environment? Impact on learning performance and student cognitions [123].

Finally, from mobile learning: Exploring the role of M-learning in elementary education [124], Exploring a curriculum app and a social communication app for EFL learning [125], Bring Your Own Devices classroom Exploring the issue of digital divide in the teaching and learning contexts [126], and An empirical study toward understanding user acceptance of bring your own device (BYOD) in higher education [127], to name a few cases.

The results in question 5, show that most research refers to experiences in virtual learning environments, followed by online courses and the educational level where more research is done is in higher education, which reflects that these are hybrid learning experiences, where being the face-to-face training process, some subject was offered virtually or with the use of technology and therefore with the accompaniment of a teacher or tutor. A challenge for the academic community is to encourage mediation research in massive open online courses, since, of the total number of publications, only 11 refer to experiences in MOOCs. The latter is important because it is about training designs without teacher accompaniment, self-instructional whose theme can contribute to training the population without with to be part of formal education.

\section{Discussion}

This systematic mapping study on mediation and online learning allowed us to know the number of publications in this field. In addition to identifying the impact, the place where the journals are published, and the specific field of mediation also let us know to what classification they refer to when addressing this topic, along with the trends on which the writings are focused. 
An interest in the topic is shown according to the number of publications (299 studies) located for the mapping, which shows the interest for the topic, as published in the period 2015-2020. Evidently, online learning at the present time constitutes a global response where everything is interconnected, but, despite the global outlook, an inequality gap persists. According to UNESCO in 2018, 260 million children were out of school, so in the face of this problem, online learning can be an alternative to reach all corners thanks to technology and public policies of governments that put education at the center as the axis of development.

The problem of inequality increased with a real impact in 2020, when the world faced a virus that forced confinement and that stopped so-called face-to-face education and turned it into virtual education, also known as emergency education. This took place because, unlike the planned class as it should be, an online educational process, emergency remote learning, forced a change in the teaching process as an alternative [128]. Based on this, it is essential to think of online learning and mediation as the answer to the training needs that the population demands.

Regarding the questions posed in the mapping of literature and according to the RQ1, it is evident that in the world of research the quantitative method dominates since the studies focus on work with a certain population to whom studies on the use or application of methodologies, strategies or resources are applied. In the literature mapping Research Competencies to Develop Academic Reading and Writing: A Systematic Literature Review [37] similar results were found, since the experimental design that corresponds to the quantitative method is the one that stands out the most in research of this nature, as in the present research. The mixed method, which is being used in the academic world presently, still has a way to go in this type of research. In the field of education and social sciences, it is evident that there is an increase in publications that address digital technologies and mixed methods, constituting an opportunity for original contributions from educational innovation [55].

Another equally important aspect obtained in RQ2 is the number of citations of the articles investigated, because it lets us know how interesting the subject matter is; having several citations of an article reflects the quality of the writing and the interest of academics in this field.

The results of RQ3 provided the geographical location of those who publish on mediation and online learning, showing interest to be mainly in the United States and other countries such as Taiwan and China. Similar results were found by [38], where the United States dominates as the country from which it is most published, therefore, research in these areas of interest to other latitudes must be strengthened. It is important to reflect that in the research, interest in the topic was also found from several regions, since even with a few contributions in this area, they are researching on mediation and online learning.

The RQ4 shows the novelty of the topic, since there is a good number of renowned journals that publish on mediation in online learning. Most of them (164 publications) are located in quartile 1, therefore, it is a topic of interest in the research community and is booming.

The technological factor is not alien to the online mediation process; they complement and need each other. Most of the writings analyzed according to RQ5, in the systematic mapping, link online mediation and learning with technology and media, even above pedagogical or cognitive mediation.

The predominance of technological mediation is due to the increase use of web $2.0 \mathrm{in}$ different areas of life, without exception in the education field, which has strengthened the processes of technological mediation [17]. Regarding pedagogical mediation, it is important to note that this is opposed to the mere transfer of information, but rather emphasizes the teacher who must have an active role [51] and demonstrates the importance of this type of mediation. In addition, in the analyzed writings, social mediation was also located, considering that although there were the technological and pedagogical factors, instead the social, group, and collaborative contexts dominate. 
In addition, in RQ5, verifying other elements of interest to be highlighted was the main goal, including interaction, communication, collaboration, and motivation. This means that researchers are conducting their studies mostly quantitative based on these points of interest.

In this context it is important to refer to other reviews whose object of interest was technological mediation, where it is addressed from different approaches, thus a review of technology-mediated learning was identified and although the interest was the participation of students, categories related to motivation and self-regulation were established [41]. An important contribution on the study of technological and pedagogical mediation is The Technological and Pedagogical Mediation in Virtual Learning Environments: contributions from Educommunicatione [42], which contributes to a theoretical analysis of what these two types of mediation represent in the educational context.

In RQ6, it is shown that learning is approached from different angles and this was possible to identify due to the mapping of literature, and in addition to online learning, other types of learning were found, which makes it possible to know that within the field of online education, interest is being focused on specific aspects such as collaboration, and social or blended learning.

There are several arguments for online learning, such as accessibility, affordability, flexibility, and lifelong learning all these together with the easy access and reaching rural and remote areas, there are strengths for its promotion [22].

Collaborative learning, also referred in the publications, is conceived as a form of learning, which arises due to the development of technology changing the way students interact with each other and with teachers, in distant geographical areas around the world [26]. The group of interest to investigate is higher education, which logically is where more research can be done in this type of learning. It is a remaining challenge to strengthen online learning processes at other educational levels.

Of the results obtained according to Figure 8, the denomination of online learning dominates in the articles and today many institutions have implemented it, as confirmed by [40]. In their research they conclude that e-learning it is a tool that arises from ICT and is available in training programs, especially at the university level. In line with these results, it was found that one of the levels of education where more research is done is Higher Education, showing a correspondence with the information obtained in this study that highlights, in addition to the type of learning, that the level of interest is the highest; on the other hand, a topic in which there is no similarity is in the MOOC since while the results of Figure 8 show very few associated publications, on the other hand, in the analyzed review, the MOOCs are the figure with the most presence in the analysis.

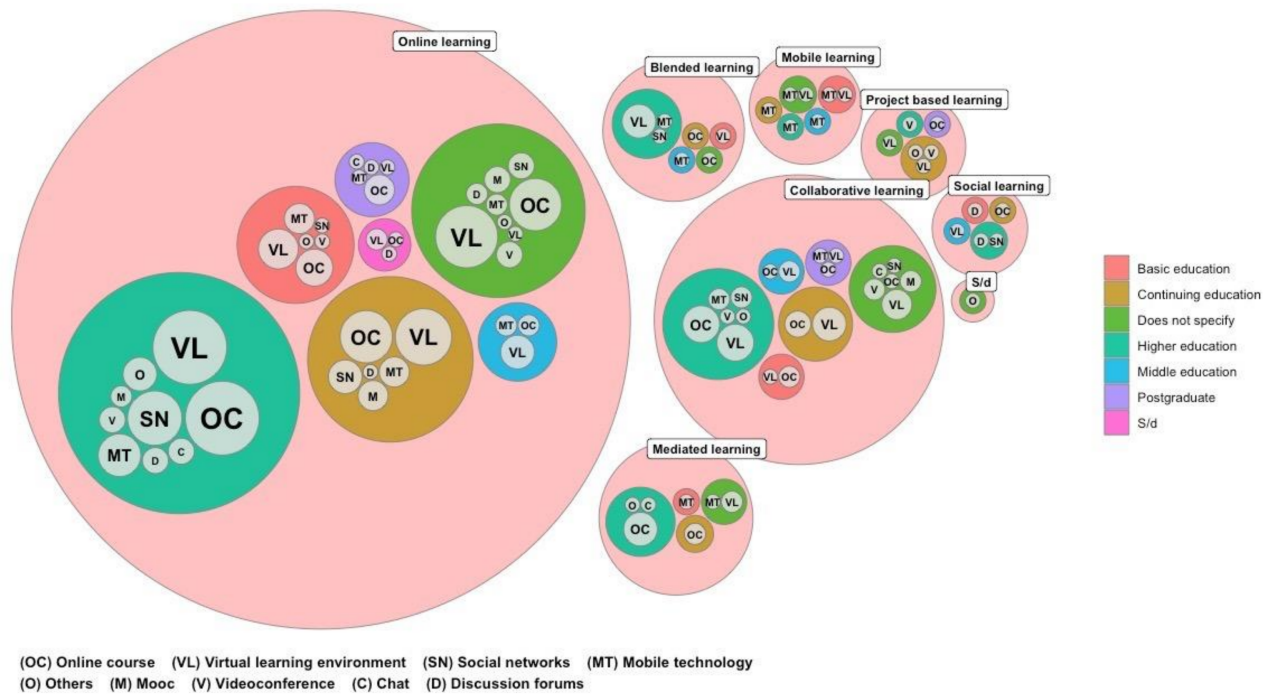

Figure 8. Type of learning, educational level, and tool or medium where it is developed. 
Another aspect that allowed the systematic mapping of literature is that the whole range of training possibilities (types of learning) is accompanied by a series of resources and technological tools that are now widely disseminated such as social networks, wikis, tablets, phones, etc. In fact, these tools could become the solution to reach more people with online learning.

Today the use of social networks for learning purposes is undeniable and according to [7] they have become learning communities where resources, doubts, solutions, and results are shared. In addition, learning in mediated environments has become the valid alternative that enables the production of knowledge and an environment conducive to collaborative participations [3].

The new trends in educational technology are inclined toward an increase in interactive activities and therefore, the collective creation of knowledge, hence virtual training has a promising future [4]. There is no doubt that virtual training has become one of the strategies for not only educational, but also professional and business contexts [5]. In fact, we are facing a crowd training alternative that through mediation and with technological support becomes something very transformative.

Some ideas for future research related to mediation and online learning are proposed below.

The tendency to write about topics focused on the field of mediation and online learning is evident and it may be of interest to expand research in this context.

In future research, studies should be strengthened that address the elements of the online educational process ranging from planning, resources, contents, materials, as well as evaluation to know the effectiveness and especially the academic performance and student satisfaction.

It is interesting within the social contribution to reflect on the trends that are currently in vogue in online study and that are oriented to elements in a social order, such as a concept of virtual learning community in which interaction, collaboration, communication, and discussion stand out, which are crucial for a type of learning that reaches more followers and that distances itself from the traditional learning model.

Future studies should also address mediation and online learning from the experience of MOOCs, whose fundamental characteristic is that they are self-instructional, therefore, mediation is shown to be a priority.

In line with the above in research where the population corresponds to the higher education level, it is important to conduct experiments, case studies, and trials, in a population with a total online offering, to further investigate the role of mediation, i.e., without the presence of teachers as mediating agents.

The pedagogical part is fundamental, considering that there is no training without mediation and that technology is a support to the educational process as long as it pursues a purpose and that this purpose is defined, therefore, the guiding thread of further research should focus on the pedagogical field, although technology is not discarded, it is necessary to look again at a transforming, meaningful training process that starts from a pedagogical basis.

\section{Limitations}

The limiting element in this paper can be determined in the selected databases. We worked with the databases of greatest impact for researchers, Web of Science and Scopus, although there could be other interesting contributions in other databases.

Another aspect to consider is that within the inclusion criteria, articles were chosen, excluding proceeding conference proceedings, books, or book chapters, which may result in not having information that contributes to other researchers in the field of interest. The systematic mapping follows a process that allows focusing attention on the topic of interest with the most relevant in the world of academia to quantify where the topic is located at the present time, although some relevant information may not be considered to be mentioned above. 


\section{Conclusions}

The main contribution of the systematic mapping is that it presents the results of what has been published in the field of mediation and online learning between 2015 and 2020, a mapping that was carried out following the methodology recommended for this type of study. A total of 299 papers were obtained, which responded to the six research questions.

We observed the type of methodology used in the research, the publications with the most citations, the geographical location of the authors to know which country contributes most in this field, and the journals in which the papers have been published, showing that publications correspond to high level journals in the academic world.

A determining element found in the approach to mediation is that it is conceived more from a technological point of view, leaving gaps for the pedagogical approach. Although the central theme is mediation, it is worth reflecting that there is a need to deepen the mediating element in research in the educational field, although technology is the medium, there is a predominant factor which is how the learning process is produced, therefore, the genesis is to value mediation and how it contributes to meaningful learning.

A substantial element that still needs to be strengthened is the research on mediation in massive open environments. Even though MOOCs emerged strongly in 2012 and are still strong almost a decade after their launch, there are few studies that show an interest in this type of training, which could be considered as an alternative to train multitudes, once formal education cannot cover or reach everyone.

Another element that was shown is that the publications refer to mediated processes, but almost always with teacher accompaniment; a totally self-directed educational process is not yet conceived. In this sense, the studies are directed to work with samples of students associated with a face-to-face model and with mixed learning models.

The implications of this article are aimed at pointing out the mediating factor from the pedagogical and technological perspective and its contribution to achieving meaningful learning; however, it is suggested that researchers and those interested in the subject of mediation direct their interest to deepen and fill research gaps on pedagogical aspects. It should be emphasized that other indicators or categories could be raised to address from online learning, the pedagogical part that as mentioned is the fundamental one if it comes to quality training, bearing in mind that especially as a result of the COVID-19 pandemic, online learning has been the alternative to train the population at its different levels, therefore, the pedagogical component merits special analysis.

Another implication is presented because professionals and researchers consider in MOOCs an analysis beyond elements such as motivation, satisfaction, abandonment, use of tools and more. This study reflects that although the interest in the selection of articles was also oriented in the MOOCs, the number obtained was low, which implies that in this offering, the topic of mediation was mostly not considered and especially that of a pedagogical type; therefore, this type of research should be strengthened.

As for online training processes without the presence of teachers and in order to improve these practices, it is necessary to emphasize the importance of mediation and the need to further explore these training offers. This study makes it evident that a good number of publications that are the product of systematic mapping, are oriented to experiences with teaching accompaniment. The research under this perspective can be an interesting help to improve the experience in self-training spaces.

This work intends to contribute to teachers, designers, and researchers to provide support that leads to enrich the mediation processes for learning environments. This paper is an invitation to continue deepening on mediation processes.

Author Contributions: Conceptualization, G.R.-C. and M.-S.R.-M.; methodology, G.R.-C. and M.S.R.-M.; validation, M.-S.R.-M.; formal analysis, G.R.-C.; investigation, G.R.-C.; resources, G.R.-C.; data curation, G.R.-C.; writing-original draft preparation, G.R.-C.; writing-review and editing, G.R.-C. and M.-S.R.-M.; visualization, G.R.-C.; supervision, M.-S.R.-M. All authors have read and agreed to the published version of the manuscript. 
Funding: This research was funded by Universidad Técnica Particular de Loja (Ecuador).

Institutional Review Board Statement: Not applicable.

Informed Consent Statement: Not applicable.

Data Availability Statement: The access site to the database of the articles under study can be found at the following address: http:/ / doi.org/10.5281/zenodo.4744632 (accessed on 10 January 2022).

Acknowledgments: The authors acknowledge the technical support of Writing Lab, Institute for the Future of Education, Tecnológico de Monterrey, Mexico, in the production of this work. We would also like to thank the Universidad Técnica Particular de Loja, Ecuador for their support.

Conflicts of Interest: The authors declare no conflict of interest.

\section{References}

1. United Nations. Transforming our world: The 2030 agenda for sustainable development. Res. Adop. Gen. Assemb. 2015. Available online: https: / /dds.cepal.org/redesoc/publicacion?id=4116 (accessed on 20 November 2021).

2. Rojas, E.; Poveda, L.; Grimblatt, N. Estado de la Banda Ancha en América Latina y el Caribe. 2016. Available online: https: // repositorio.cepal.org/bitstream/handle/11362/40528/s1601049_es.pdf?sequence=6\&isallowed=y (accessed on 14 October 2021).

3. Slomski, V.G.; de Araujo, A.M.P.; Santana, A.S.; Weffort, E.F.J. Tecnologias e Mediação Pedagógica Na Educação Superior a Distância. J. Inf. Syst. Technol. Manag. 2016, 13, 131-150. [CrossRef]

4. Avello Martínez, R.; Duart, J.M. Nuevas Tendencias de Aprendizaje Colaborativo En E-Learning: Claves Para Su Implementación Efectiva. Estud. Pedagóg. 2016, 42, 271-282. [CrossRef]

5. Garcia Marcos, C.J.; Cabero Almenara, J. Evolución y Estado Actual Del E-Learning En La Formación Profesional Española. RIED Rev. Iberoam. Educ. Dist. 2016, 19, 167. [CrossRef]

6. Copriady, J. Self-Motivation as a Mediator for Teachers' Readiness in Applying ICT in Teaching and Learning. Proc. Soc. Behav. Sci. 2015, 176, 699-708. [CrossRef]

7. García-Peñalvo, F.J.; Fidalg-Blanco, Á.; Sein-Echaluce, M. Los MOOC: Un análisis desde una perspectiva de la innovación institucional universitaria. Cuest. Univ. 2017, 9, 117-135. Available online: https://zaguan.unizar.es/record/63528 (accessed on 5 June 2021).

8. Quintero Ortega, S.P.; Díaz Correa, Á.M.; Ortiz Russi, G.E. Modelo de mediaciones pedagógicas y tecnológicas para entender e incorporar adecuadamente procesos pedagógicos-comunicativos-tecnológicos de ambientes virtuales de aprendizaje en la Policia Nacional de Colombia. Rev. Logos Cienc. Tecnol. 2015, 6, 188-197. [CrossRef]

9. Gabelas, J.A.; Marta-Lazo, C.; González Aldea, P. The relational factor in media convergence: An emerging proposal. Anàlisi 2015, 53, 20. [CrossRef]

10. De Pablos Pons, J. Las tecnologías digitales y su impacto en la Universidad. Las nuevas mediaciones. RIED Rev. Iberoam. Educ. Distancia 2018, 21, 83. [CrossRef]

11. Jaramillo Morales, C.O.; Conde Pinzón, G.E.; Londoño Villamil, G. Modelo de diseño didáctico para la construcción de cursos virtuales: Una propuesta en la modalidad de educación a distancia de la Universidad de la Amazonia. Acad. Virtual. 2020, 13, 23-36. [CrossRef]

12. Valenzuela, J.R. La innovación como objeto de investigación en educación: Problemas, tensiones y experiencias. Innovación educativa investigación, formación, vinculación y visibilidad. In Innovación Educativa Investigación, Formación, Vinculación y Visibilidad; Síntesis: Madrid, Spain, 2017; pp. 29-51.

13. Trujillo Torres, J.M.; Aznar Díaz, I.; Cáceres Reche, M.P. Análisis Del Uso e Integración de Redes Sociales Colaborativas En Comunidades de Aprendizaje de La Universidad de Granada (España) y John Moores de Liverpool (Reino Unido). Rev. Complut. Educ. 2015, 26, 289-311. [CrossRef]

14. Redding, S.; Twyman, J.; Murphy, M. What Is an Innovation in Learning? In Handbook on Innovations in Learning Part 1; Center on Innovations in Learning: Philadelphia, PA, USA, 2014; pp. 3-14.

15. Tébar, L. El Perfil del Profesor Mediador: Pedagogía de la Mediación; Ediciones Universidad de Salamanca: Salamanca, Spain, 2003.

16. Tobon, S.; Martinez, J.E.; Valdez, E.; Quiriz, T. Prácticas pedagógicas: Análisis mediante la cartografía conceptual. Rev. Esp. 2018, 39, 1-16. Available online: http:/ / www.revistaespacios.com/cited2017/cited2017-31.html (accessed on 12 July 2021).

17. Veytia, M.G. Manejo de herramientas de la web 2.0 como base para fortalecer procesos de mediación tecnológica. Rev. Iberoa. Inv. Des. Edu. RIDE 2015, 6, 1-18. Available online: http://www.ride.org.mx/index.php/RIDE/article/view/140 (accessed on 16 July 2021).

18. Guetta, S. The Feuerstein approach to intercultural education and respect for human rights. Bull. Transil. Univer. Bras. Ser. VII Soc. Scien. Law 2016, 9, 181-186. Available online: https:/ / www.ceeol.com/search/article-detail?id=509958 (accessed on 24 August 2021).

19. Tzuriel, D. Mediated Learning Experience and Cognitive Modifiability. J. Cogn. Educ. Psychol. 2014, 12, 59-80. Available online: https://www.researchgate.net/publication/270526553_Mediated_Learning_Experience_and_Cognitive_Modifiability (accessed on 3 September 2021). [CrossRef] 
20. Izard, M.; Francisco, J. Tutoría en espacios virtuales de aprendizaje y procesos de mediación didáctica. In Investigación y tecnologías de la información y comunicación al servicio de la innovación educativa; Ediciones Universidad de Salamanca: Salamanca, Spain, 2008; pp. 113-140.

21. Ausubel, D. Teoría del aprendizaje signifactivo. Fascículos De CEIF 1983, 1, 1-10.

22. Dhawan, S. Online Learning: A Panacea in the Time of COVID-19 Crisis. J. Educ. Technol. Syst. 2020, 49, 5-22. [CrossRef]

23. Mayer, R.E. Thirty Years of Research on Online Learning. Appl. Cogn. Psychol. 2019, 33, 152-159. [CrossRef]

24. Kentnor, H. Digital Commons @ DU Sturm College of Law: Faculty Scholarship Distance Education and the Evolution of Online Learning in the United States. Med.-Leg. 2015, 17, 22-34.

25. Panigrahi, R.; Srivastava, P.R.; Sharma, D. Online Learning: Adoption, Continuance, and Learning Outcome-A Review of Literature. Int. J. Inf. Manag. 2018, 43, 1-14. [CrossRef]

26. Jeong, H.; Hmelo-Silver, C.E. Seven Affordances of Computer-Supported Collaborative Learning: How to Support Collaborative Learning? How Can Technologies Help? Educ. Psychol. 2016, 51, 247-265. [CrossRef]

27. Sun, Z.; Liu, R.; Luo, L.; Wu, M.; Shi, C. Exploring Collaborative Learning Effect in Blended Learning Environments: Exploring Collaborative Learning Effect. J. Comput. Assist. Learn. 2017, 33, 575-587. [CrossRef]

28. Cleveland-Innes, M.; Wilton, D. Guide to Blended Learning. Commonwealth of Learning. 2018. Available online: http://hdl.handle. net/11599/3095 (accessed on 26 April 2021).

29. Bowyer, J.; Chambers, L. Evaluating Blended Learning: Bringing the Elements Together. Res. Matters Camb. Assess. Publ. 2017, 1,17-26. Available online: https:/ /learning.huph.edu.vn/pluginfile.php/7529/mod_resource/content/1/375446-evaluatingblended-learning-bringing-the-elements-together.pdf (accessed on 17 June 2021).

30. Margolis, A.R.; Porter, A.L.; Pitterle, M.E. Best Practices for Use of Blended Learning. Am. J. Pharm. Educ. 2017, 81, 49. [CrossRef] [PubMed]

31. Crompton, H.; Burke, D. The Use of Mobile Learning in Higher Education: A Systematic Review. Comput. Educ. 2018, 123, 53-64. [CrossRef]

32. Crompton, H.; Burke, D.; Gregory, K.H.; Gräbe, C. The Use of Mobile Learning in Science: A Systematic Review. J. Sci. Educ. Technol. 2016, 25, 149-160. [CrossRef]

33. Al-Emran, M.; Elsherif, H.M.; Shaalan, K. Investigating Attitudes towards the Use of Mobile Learning in Higher Education. Comput. Hum. Behav. 2016, 56, 93-102. [CrossRef]

34. Guo, P.; Saab, N.; Post, L.S.; Admiraal, W. A Review of Project-Based Learning in Higher Education: Student Outcomes and Measures. Int. J. Educ. Res. 2020, 102, 101586. [CrossRef]

35. Shpeizer, R. Towards a Successful Integration of Project-Based Learning in Higher Education: Challenges, Technologies and Methods of Implementation. Univers. J. Educ. Res. 2019, 7, 1765-1771. [CrossRef]

36. Chu, S.K.W.; Zhang, Y.; Chen, K.; Chan, C.K.; Lee, C.W.Y.; Zou, E.; Lau, W. The Effectiveness of Wikis for Project-Based Learning in Different Disciplines in Higher Education. Internet High Educ. 2017, 33, 49-60. [CrossRef]

37. Castillo-Martínez, I.M.; Ramírez-Montoya, M.S. Research competencies to develop academic reading and writing: A systematic literature review. Front. Educ. 2021, 5, 294. [CrossRef]

38. Fernández-Luque, A.-M.; Ramírez-Montoya, M.-S.; Cordón-García, J.-A. Training in digital competencies for health professionals: Systematic mapping (2015-2019). Prof. Inf. 2021, 30, e300213. [CrossRef]

39. Farid, S.; Ahmad, R.; Niaz, I.A.; Arif, M.; Shamshirband, S.; Khattak, M.D. Identification and Prioritization of Critical Issues for the Promotion of E-Learning in Pakistan. Comput. Hum. Behav. 2015, 51, 161-171. [CrossRef]

40. Valverde-Berrocoso, J.; Garrido-Arroyo, M.D.C.; Burgos-Videla, C.; Morales-Cevallos, M.B. Trends in Educational Research about E-Learning: A Systematic Literature Review (2009-2018). Sustainability 2020, 12, 5153. [CrossRef]

41. Henrie, C.R.; Halverson, L.R.; Graham, C.R. Measuring Student Engagement in Technology-Mediated Learning: A Review. Comput. Educ. 2015, 90, 36-53. [CrossRef]

42. Fofonca, E.; Zmorzenski Valduga Schoninger, R.R.; Sílvia da Costa, C. A Mediação Tecnológica e Pedagógica Em Ambientes Virtuais de Aprendizagem: Contribuições das Dimensões da Educomunicação. Rev. Tempos Espaç. Em Educ. 2018, 11, 267-278. [CrossRef]

43. García, A.; Ramírez, M. Systematic Mapping of Scientific Production on Open Innovation (2015-2018): Opportunities for sustainable training environments. Sustainability 2019, 11, 1781.

44. Kitchenham, B.; Charters, S. Guidelines for Performing Systematic Literature Reviews in Software Engineering. 2007. Available online: http:/ / citeseerx.ist.psu.edu/viewdoc/summary?doi=10.1.1.117.471 (accessed on 15 October 2021).

45. Kitchenham, B. Procedures for Performing Systematic Reviews, Version 1.0. Emp. Soft. Eng. 2004, 33, 1-16. Available online: http://www.elizabete.com.br/rs/Tutorial_IHC_2012_files/Conceitos_RevisaoSistematica_kitchenham_2004.pdf (accessed on 20 October 2021).

46. Kitchenham, B.; Pretorius, R.; Budgen, D.; Pearl Brereton, O.; Turner, M.; Niazi, M.; Linkman, S. Systematic Literature Reviews in Software Engineering-A Tertiary Study. Inf. Softw. Technol. 2010, 52, 792-805. [CrossRef]

47. Petersen, K.; Feldt, R.; Mujtaba, S.; Mattsson, M. Systematic Mapping Studies in Software Engineering. In Proceedings of the 12th International Conference on Evaluation and Assessment in Software Engineering (EASE), Bari, Italy, 26-27 June 2008; pp. 1-10.

48. López-Meneses, E.; Vázquez-Cano, E.; Román-Graván, P. Analysis and implications of the impact of MOOC movement in the scientific community: JCR and Scopus (2010-13). Comunicar 2015, 22, 73-80. [CrossRef]

49. Calderón, A.; Ruiz, M. A Systematic Literature Review on Serious Games Evaluation: An Application to Software Project Management. Comput. Educ. 2015, 87, 396-422. [CrossRef] 
50. Moher, D.; Liberati, A.; Tetzlaff, J.; Altman, D.G. Preferred Reporting Items for Systematic Reviews and Meta-Analyses: The PRISMA Statement. PLoS Med. 2009, 6, e1000097. [CrossRef] [PubMed]

51. Avogadro, M.E.; Quiroga, S.R. La mediación tecnológica y las TIC: Fenómenos y objetos técnicos. Razón Y Palabra 2016, 92, 1-18. Available online: http:/ / www.razonypalabra.org.mx/N/N92/Varia/27_AvogadroQuiroga_V92.pdf (accessed on 3 November 2021).

52. Ooi, K.-B.; Hew, J.-J.; Lee, V.-H. Could the Mobile and Social Perspectives of Mobile Social Learning Platforms Motivate Learners to Learn Continuously? Comput. Educ. 2018, 120, 127-145. [CrossRef]

53. Bartau, I.; Aierbe, A.; Oregui, E. Mediación parental del uso de Internet en el alumnado de Primaria: Creencias, estrategias y dificultades. Com. Rev. Cen. Iberoam. Comu. Educ. 2018, 54, 71-79.

54. Creswell, J.W. Research Design: Qualitative, Quantitative, and Mixed Methods Approaches, 4th ed.; SAGE Publications: California, CA, USA, 2014.

55. Ramírez, M.S.; Lugo, J. Revisión sistemática de métodos mixtos en el marco de la innovación educativa. Comunicar 2020, 600, 9-20.

56. Kock, N.; Chatelain-Jardón, R. Surprise-Enhanced and Technology-Mediated Learning: A Two-Country Study. Cogn. Technol. Work 2016, 18, 105-119. [CrossRef]

57. Hsu, C.-C.; Chiu, C.-H.; Lin, C.-H.; Wang, T.-I. Enhancing skill in constructing scientific explanations using a structured argumentation scaffold in scientific inquiry. Comput. Educ. 2015, 91, 46-59. [CrossRef]

58. Tsai, C.-Y. The effect of online argumentation of socio-scientific issues on students' scientific competencies and sustainability attitudes. Comput. Educ. 2018, 116, 14-27. [CrossRef]

59. Wakefield, J.; Frawley, J.K.; Tyler, J.; Dyson, L.E. The impact of an iPad-supported annotation and sharing technology on university students' learning. Comput. Educ. 2018, 122, 243-259. [CrossRef]

60. Biddix, J.P.; Chung, C.J.; Park, H.W. The Hybrid Shift: Evidencing a Student-Driven Restructuring of the College Classroom. Comput. Educ. 2015, 80, 162-175. [CrossRef]

61. Hong, H.-Y.; Chai, C.S. Principle-based design: Development of adaptive mathematics teaching practices and beliefs in a knowledge building environment. Comput. Educ. 2017, 115, 38-55. [CrossRef]

62. Humphry, D.; Hampden-Thompson, G. Primary School Pupils' Emotional Experiences of Synchronous Audio-Led Online Communication during Online One-to-One Tuition. Comput. Educ. 2019, 135, 100-112. [CrossRef]

63. Vogler, J.S.; Munsell, S.E.; Knutson, D. LOLsquared: When Laughing-out-Loud and Learning-on-Line Intermingle in a ComputerMediated Classroom Discussion. Comput. Educ. 2019, 140, 103597. [CrossRef]

64. Schiller, S.Z. CHAT for Chat: Mediated Learning in Online Chat Virtual Reference Service. Comput. Hum. Behav. 2016, 65, 651-665. [CrossRef]

65. Yücel, Ü.A.; Usluel, Y.K. Knowledge building and the quantity, content and quality of the interaction and participation of students in an online collaborative learning environment. Comput. Educ. 2016, 97, 31-48. [CrossRef]

66. Butz, N.T.; Stupnisky, R.H. Improving Student Relatedness through an Online Discussion Intervention: The Application of Self-Determination Theory in Synchronous Hybrid Programs. Comput. Educ. 2017, 114, 117-138. [CrossRef]

67. Beltrán Hernández de Galindo, M.D.J.; Romero-Rodriguez, L.M.; Ramirez Montoya, M.S. Entrepreneurship Competencies in Energy Sustainability MOOCs. J. Entrep. Emerg. Econ. 2019, 11, 598-616. [CrossRef]

68. Forkosh-Baruch, A.; Hershkovitz, A. Broadening Communication yet Holding Back: Teachers' Perceptions of Their Relationship with Students in the SNS-Era. Educ. Inf. Technol. 2018, 23, 725-740. [CrossRef]

69. Vázquez-Cano, E.; González, A.I.H.; Sáez-López, J.M. An Analysis of the Orthographic Errors Found in University Students' Asynchronous Digital Writing. J. Comput. High. Educ. 2019, 31, 1-20. [CrossRef]

70. Tsai, C.-Y.; Lin, C.-N.; Shih, W.-L.; Wu, P.-L. The Effect of Online Argumentation upon Students' Pseudoscientific Beliefs. Comput. Educ. 2015, 80, 187-197. [CrossRef]

71. Ainin, S.; Naqshbandi, M.M.; Moghavvemi, S.; Jaafar, N.I. Facebook usage, socialization and academic performance. Comput. Educ. 2015, 83, 64-73. [CrossRef]

72. Pang, L.; Jen, C.C. Inclusive Dyslexia-Friendly Collaborative Online Learning Environment: Malaysia Case Study. Educ. Inf. Technol. 2018, 23, 1023-1042. [CrossRef]

73. Vogler, J.S.; Schallert, D.L.; Jordan, M.E.; Song, K.; Sanders, A.J.Z.; Te Chiang, Y.-H.Y.; Lee, J.-E.; Park, J.H.; Yu, L.-T. Life history of a topic in an online discussion: A complex systems theory perspective on how one message attracts class members to create meaning collaboratively. Int. J. Comput. Support. Collab. Learn. 2017, 12, 173-194. [CrossRef]

74. Cheng, X.; Fu, S.; Sun, J.; Han, Y.; Shen, J.; Zarifis, A. Investigating Individual Trust in Semi-Virtual Collaboration of Multicultural and Unicultural Teams. Comput. Hum. Behav. 2016, 62, 267-276. [CrossRef]

75. Torrey, T.; Krutka, D.G.; Carpenter, J.P. “Together we are better”: Professional learning networks for teachers. Comput. Educ. 2016, 102, 15-34.

76. Binder, J.F.; Cebula, K.; Metwally, S.; Vernon, M.; Atkin, C.; Mitra, S. Conversational Engagement and Mobile Technology Use. Comput. Hum. Behav. 2019, 99, 66-75. [CrossRef]

77. Smith, E.E. "A Real Double-Edged Sword:" Undergraduate Perceptions of Social Media in Their Learning. Comput. Educ. 2016, 103, 44-58. [CrossRef]

78. Farr, F.; Riordan, E. Tracing the Reflective Practices of Student Teachers in Online Modes. ReCALL 2015, 27, 104-123. [CrossRef]

79. Levak, N.; Son, J.-B. Facilitating Second Language Learners' Listening Comprehension with Second Life and Skype. ReCALL 2017, 29, 200-218. [CrossRef] 
80. Järvelä, S.; Kirschner, P.A.; Panadero, E.; Malmberg, J.; Phielix, C.; Jaspers, J.; Koivuniemi, M.; Järvenoja, H. Enhancing Socially Shared Regulation in Collaborative Learning Groups: Designing for CSCL Regulation Tools. Educ. Technol. Res. Dev. 2015, 63, 125-142. [CrossRef]

81. Eid, M.I.M.; Al-Jabri, I.M. Social networking, knowledge sharing, and student learning: The case of university students. Comput. Educ. 2016, 99, 14-27. [CrossRef]

82. Jaggars, S.S.; Xu, D. How Do Online Course Design Features Influence Student Performance? Comput. Educ. 2016, 95, 270-284. [CrossRef]

83. Wei, H.-C.; Peng, H.; Chou, C. Can More Interactivity Improve Learning Achievement in an Online Course? Effects of College Students' Perception and Actual Use of a Course-Management System on Their Learning Achievement. Comput. Educ. 2015, 83, 10-21. [CrossRef]

84. Kent, C.; Laslo, E.; Rafaeli, S. Interactivity in Online Discussions and Learning Outcomes. Comput. Educ. 2016, 97, 116-128. [CrossRef]

85. Stowell, J.R. Use of Clickers vs. Mobile Devices for Classroom Polling. Comput. Educ. 2015, 82, 329-334. [CrossRef]

86. Luo, N.; Zhang, M.; Qi, D. Effects of Different Interactions on Students' Sense of Community in e-Learning Environment. Comput. Educ. 2017, 115, 153-160. [CrossRef]

87. Lee, J.; Bonk, C.J. Social Network Analysis of Peer Relationships and Online Interactions in a Blended Class Using Blogs. Internet High. Educ. 2016, 28, 35-44. [CrossRef]

88. Passig, D.; Tzuriel, D.; Eshel-Kedmi, G. Improving Children's Cognitive Modifiability by Dynamic Assessment in 3D Immersive Virtual Reality Environments. Comput. Educ. 2016, 95, 296-308. [CrossRef]

89. Chen, J.C. The Crossroads of English Language Learners, Task-Based Instruction, and 3D Multi-User Virtual Learning in Second Life. Comput. Educ. 2016, 102, 152-171. [CrossRef]

90. Imlawi, J.; Gregg, D.; Karimi, J. Student Engagement in Course-Based Social Networks: The Impact of Instructor Credibility and Use of Communication. Comput. Educ. 2015, 88, 84-96. [CrossRef]

91. Tsay, C.H.-H.; Kofinas, A.; Luo, J. Enhancing Student Learning Experience with Technology-Mediated Gamification: An Empirical Study. Comput. Educ. 2018, 121, 1-17. [CrossRef]

92. Wise, A.F.; Cui, Y.; Jin, W.; Vytasek, J. Mining for Gold: Identifying Content-Related MOOC Discussion Threads across Domains through Linguistic Modeling. Internet High. Educ. 2017, 32, 11-28. [CrossRef]

93. Han, J.; Jo, M.; Hyun, E.; So, H.-J. Examining Young Children's Perception toward Augmented Reality-Infused Dramatic Play. Educ. Technol. Res. Dev. 2015, 63, 455-474. [CrossRef]

94. Zhang, J. Can MOOCs Be Interesting to Students? An Experimental Investigation from Regulatory Focus Perspective. Comput. Educ. 2016, 95, 340-351. [CrossRef]

95. Shadiev, R.; Huang, Y.-M. Facilitating Cross-Cultural Understanding with Learning Activities Supported by Speech-to-Text Recognition and Computer-Aided Translation. Comput. Educ. 2016, 98, 130-141. [CrossRef]

96. Tsiotakis, P.; Jimoyiannis, A. Critical Factors towards Analysing Teachers' Presence in on-Line Learning Communities. Internet High. Educ. 2016, 28, 45-58. [CrossRef]

97. Walther, J.B.; Hoter, E.; Ganayem, A.; Shonfeld, M. Computer-Mediated Communication and the Reduction of Prejudice: A Controlled Longitudinal Field Experiment among Jews and Arabs in Israel. Comput. Human Behav. 2015, 52, 550-558. [CrossRef]

98. Zhang, S.; Liu, Q.; Chen, W.; Wang, Q.; Huang, Z. Interactive Networks and Social Knowledge Construction Behavioral Patterns in Primary School Teachers' Online Collaborative Learning Activities. Comput. Educ. 2017, 104, 1-17. [CrossRef]

99. Korkmaz, Ö.; Çakir, R.; Özden, M.Y. A Validity and Reliability Study of the Computational Thinking Scales (CTS). Comput. Human Behav. 2017, 72, 558-569. [CrossRef]

100. Zheng, B.; Warschauer, M. Participation, Interaction, and Academic Achievement in an Online Discussion Environment. Comput. Educ. 2015, 84, 78-89. [CrossRef]

101. Symeonides, R.; Childs, C. The personal experience of online learning: An interpretative phenomenological analysis. Comput. Hum. Behav. 2015, 51, 539-545. [CrossRef]

102. Chen, X.; Siau, K. Technology-Mediated Synchronous Virtual Education: An Empirical Study. J. Database Manag. 2016, 27, 39-63. [CrossRef]

103. Bower, M. Technology-mediated Learning Theory. Br. J. Educ. Technol. 2019, 50, 1035-1048. [CrossRef]

104. Marriott, R.; Ferreira, J.; Behrens, M.; Torres, P. The necessary knowledge for online education: Teaching and learning to produce knowledge. Eurasia J. Math. Sci. Technol. Educ. 2018, 14, 2097-2106. [CrossRef]

105. De Sales Júnior, F.M.; Ramos, M.A.D.S.; de Pinho, A.L.S.; Santa Rosa, J.G.D.S. Pedagogical usability: A theoretical essay for e-learning. Holos 2016, 1, 3. [CrossRef]

106. Madriñán Rodríguez, P. LIES: Learning Immersive Experiences Significative. Sist. Telemát. 2018, 16, 71-82. [CrossRef]

107. Shintaku, K. The Interplay of Game Design and Pedagogical Mediation in Game-Mediated Japanese Learning. Int. J. Comput.Assist. Lang. Learn. Teach. 2016, 6, 36-55. [CrossRef]

108. Öztok, M.; Kehrwald, B.A. Social Presence Reconsidered: Moving beyond, Going Back, or Killing Social Presence. Distance Educ. 2017, 38, 259-266. [CrossRef]

109. Friedlander, V. Social relations of cyber-mediated learning platforms: Symmetry, relation, and evolution. Int. J. Contin. Eng. Educ. Life Long Learn. 2015, 25, 39. [CrossRef]

110. Molinillo, S.; Aguilar-Illescas, R.; Anaya-Sánchez, R.; Vallespín-Arán, M. Exploring the Impacts of Interactions, Social Presence and Emotional Engagement on Active Collaborative Learning in a Social Web-Based Environment. Comput. Educ. 2018, 123, 41-52. [CrossRef] 
111. Cesareni, D.; Cacciamani, S.; Fujita, N. Role Taking and Knowledge Building in a Blended University Course. Int. J. Comput. Support. Collab. Learn. 2016, 11, 9-39. [CrossRef]

112. Chen, V.H.H.; Chng, G.S. Active and restrictive parental mediation over time: Effects on youths' self-regulatory competencies and impulsivity. Comput. Educ. 2016, 98, 206-212. [CrossRef]

113. Lau, W.W.F.; Yuen, A.H.K. The relative importance of paternal and maternal parenting as predictors of adolescents' home Internet use and usage. Comput. Educ. 2016, 102, 224-233. [CrossRef]

114. Torrecillas-Lacave, T.; Vázquez-Barrio, T.; Monteagudo-Barandalla, L. Percepción de los padres sobre el empoderamiento digital de las familias en hogares hiperconectados. Prof. Inf. 2017, 26, 97. [CrossRef]

115. Kennedy, C.; Rhoads, C.; Leu, D.J. Online research and learning in science: A one-to-one laptop comparison in two states using performance based assessments. Comput. Educ. 2016, 100, 141-161. [CrossRef]

116. Karaoglan Yilmaz, F.G.; Yilmaz, R. Impact of Pedagogic Agent-Mediated Metacognitive Support towards Increasing Task and Group Awareness in CSCL. Comput. Educ. 2019, 134, 1-14. [CrossRef]

117. Abe, Y.; Mashiko, Y. The Effects of Synchronous CMC on English Proficiency and Social Presence, Affinity for Partners: Text versus Video Chat between Japanese and Philippine EFL Learners. IEEJ Trans. Fundam. Mater. 2019, 139, 486-491. [CrossRef]

118. Silvis, D.; Taylor, K.H.; Stevens, R. Community Technology Mapping: Inscribing Places When "Everything Is on the Move". Int. J. Comput. Support. Collab. Learn. 2018, 13, 137-166. [CrossRef]

119. Puhl, T.; Tsovaltzi, D.; Weinberger, A. Blending Facebook Discussions into Seminars for Practicing Argumentation. Comput. Hum. Behav. 2015, 53, 605-616. [CrossRef]

120. Law, K.M.Y.; Geng, S.; Li, T. Student Enrollment, Motivation and Learning Performance in a Blended Learning Environment: The Mediating Effects of Social, Teaching, and Cognitive Presence. Comput. Educ. 2019, 136, 1-12. [CrossRef]

121. Greene, K.; Hale, W. The state of 21st century learning in the K-12 world of the United States: Online and blended learning opportunities for American elementary and secondary students. J. Educ. Multimed. Hypermedia 2017, 26, 131-159.

122. Hong, J.-C.; Hwang, M.-Y.; Tai, K.-H.; Kuo, Y.-C. Parental monitoring predicts students' prosocial and impulsive tendencies relevant to consequence-based reasoning in a blended learning environment. Interact. Learn. Environ. 2016, 24, 1534-1551. [CrossRef]

123. Thai, N.T.T.; De Wever, B.; Valcke, M. Face-to-face, Blended, Flipped, or Online Learning Environment? Impact on Learning Performance and Student Cognitions. J. Comput. Assist. Learn. 2020, 36, 397-411. [CrossRef]

124. Ju Chen, H. Exploring the Role of M-Learning in Elementary Education. J. Inf. Technol. Educ. Res. 2017, 16, 459-474. [CrossRef]

125. Zou, B.; Li, H.; Li, J. Exploring a Curriculum App and a Social Communication App for EFL Learning. Comput. Assist. Lang. Learn. 2018, 31, 694-713. [CrossRef]

126. Adhikari, J.; Mathrani, A.; Scogings, C. Bring Your Own Devices Classroom: Exploring the Issue of Digital Divide in the Teaching and Learning Contexts. Interact. Technol. Smart Educ. 2016, 13, 323-343. [CrossRef]

127. Cheng, G.; Guan, Y.; Chau, J. An empirical study towards understanding user acceptance of bring your own device (BYOD) in higher education. Australas. J. Educ. Technol. 2016, 32. [CrossRef]

128. Hodges, C.B.; Moore, S.; Lockee, B.B.; Trust, T.; Bond, M.A. The Difference between Emergency Remote Teaching and Online Learning. 2020. Available online: http:/ / hdl.handle.net/10919/104648 (accessed on 23 November 2021). 